\title{
Penerapan Model Discovery Learning untuk Meningkatkan Kemampuan Berpikir Kritis dan Kecakapan Kerjasama pada Pembelajaran IPA Siswa Kelas V SD Negeri 32 Bengkulu Tengah
}

\author{
Sri Hartati \\ Program Magister Pendidikan Dasar Universitas Bengkulu. \\ srih084@gmail.com \\ Irwan Koto \\ Program Magister Pendidikan Dasar Universitas Bengkulu. \\ Daimun Hambali \\ Program Magister Pendidikan Dasar Universitas Bengkulu.
}

\begin{abstract}
Penelitian ini bertujuan untuk mendeskripsikan penerapan model discovery learning sehingga dapat meningkatkan kemampuan berpikir kritis dan kecakapan kerjasama siswa pada pembelajaran IPA. Subjek penelitian adalah siswa kelas V SD Negeri 32 Bengkulu Tengah berjumlah 24 siswa. Instrumen yang digunakan yaitu lembar observasi keterlaksanaan pembelajaran, tes kemampuan berpikir kritis, dan lembar observasi kecakapan kerjasama siswa. Teknik pengumpulan data adalah lembar observasi dan tes. Data observasi dianalisis rata-rata skor, skor tertinggi, skor terendah dan persentase ketuntasan belajar klasikal, sedangkan data tes menggunakan rumus rata-rata nilai dan persentase ketuntasan belajar klasikal. Hasil yang dicapai dalam penelitian ini adalah pada indikator memfokuskan pertanyaan sebesar $81 \%$. Indikator menjawab pertanyaan tentang suatu penjelasan sebesar $82 \%$. Indikator membangun keterampilan dasar sebesar 90\%. Indikator menyimpulkan sebesar 80\%. Kecakapan kerjasama siswa pada indikator memberikan pendapat dalam kerja kelompok sebesar $87 \%$ dengan kategori baik. Indikator memberi dan mendengarkan pendapat temannya sebesar $82 \%$ dengan kategori baik. Indikator ikut dalam kegiatan sosial sebesar $87 \%$ dengan kategori baik. Berdasarkan hasil penelitian disimpulkan bahwa Penerapan Model Discovery Learning untuk Meningkatkan Kemampuan Berpikir Kritis dan Kecakapan Kerjasama Pada Pembelajaran IPA Siswa Kelas V SD Negeri 32 Bengkulu Tengah.

Kata Kunci: Discovery Learning, Kemampuan Berpikir Kritis, Kecakapan Kerjasama
\end{abstract}


Penerapan Model Discovery Learning untuk Meningkatkan Kemampuan Berpikir Kritis dan Kecakapan Kerjasama pada Pembelajaran IPA Siswa Kelas V SD Negeri 32

Bengkulu Tengah

\section{Pendahuluan}

Pembelajaran IPA pada umumnya membahas tentang gejala alam yang disusun secara sistematis didasarkan pada hasil percobaan (Samatowa, 2016: 3). Pembelajaran IPA diharapkan dapat menjadi wahana bagi siswa untuk mempelajari diri sendiri dan alam sekitar melalui pengalaman langsung.

Guru sebagai fasilitator dalam pembelajaran tidak hanya menyampaikan materi, guru harus mampu memberikan variasi mengajar, menyiapkan situasi yang melatih siswa untuk berani bertanya, membuat sesuatu, mengamati, melakukan percobaan, mengkomunikasikan hasil percobaan dan menemukan fakta atau konsep sendiri. Proses pembelajaran siswa dituntut ikut berperan aktif dalam upaya menemukan pengetahuan, konsep, teori dan kesimpulan. Agar proses tersebut terlaksana, diperlukan peran guru sebagai pengarah kegiatan pembelajaran sehingga siswa tidak hanya memperoleh pengetahuan namun juga mampu membangun pengetahuan untuk dirinya sendiri dan pembelajaran berpusat pada siswa bukan berpusat pada guru (Depdiknas, 2006: 281).

Pelaksanaan pembelajaran di SD Negeri 32 Bengkulu Tengah pada mata pelajaran IPA secara umum masih banyak kendala yang dihadapi. Berdasarkan hasil wawancara peneliti dengan guru kelas V diperoleh data bahwa pelajaran IPA dianggap sebagai pelajaran yang sulit, siswa masih cenderung pasif dalam kegiatan pembelajaran, siswa terlihat bosan dengan pembelajaran yang sedang berlangsung, siswa belum mampu merumuskan masalah yang akan dipecahkan tentang materi dalam pembelajaran, perumusan masalah merupakan kegiatan pembelajaran yang melatih siswa berpikir kritis. Siswa belum mampu memfokuskan pertanyaan dari suatu penjelasan, siswa belum mampu menjawab pertanyaan dari suatu penjelasan yang diberikan, siswa juga belum mampu mengemukakan usulan jawaban, menurut Faiz (2012: 14) seorang pemikir kritis harus mencoba mengemukakan usulan jawaban yang dapat dimanfaatkan sebagai solusi dari masalah.

Hasil belajar IPA siswa masih di bawah kriteria ketuntasan minimal, baik secara individual maupun secara klasikal. Pada kondisi awal, nilai yang diperoleh siswa sebanyak 18 dari 24 siswa tidak memenuhi KKM yang ditentukan yaitu di bawah 70. Hal ini disebabkan karena dalam pembelajaran guru hanya mengandalkan teori, siswa hanya menyalin informasi dari buku cetak dan siswa belum memliki keberanian untuk menyimpulkan hasil diskusi. Siswa masih belum mampu berpikir kritis disebabkan karena faktor lingkungan yang tidak mendukung siswa untuk belajar dan lebih mampu berpikir kritis. 
Kegiatan pembelajaran yang dilakukan guru belum memanfaatkan media pembelajaran yang ada disekitarnya. Siswa terlihat belajar secara individual, mereka belum mengerti belajar secara kelompok, sesekali guru memberikan tugas kelompok, siswa hanya mau berkelompok dengan teman sebangkunya saja, siswa sulit kerjasama dengan teman lain di dalam kelompok. Menurut Samatowa (2016:63) pembelajaran IPA hendaknya melibatkan siswa secara langsung pada kejadian nyata yang dapat dimengerti oleh siswa dan memungkinkan terjadi interaksi sosial antar siswa.

Menurut Susan dalam Haryanto (2011: 176) siswa juga harus memiliki kecapakan hidup yaitu kerjasama. Hasil wawancara dengan guru kelas V diperoleh bahwa siswa belum berani mengungkapkan pendapatnya dalam kelompok. Ketika belajar kelompok siswa belum berani memberikan ide dan mendengarkan pendapat temannya. Salah satu alternatif untuk meningkatkan kemampuan berpikir kritis dan kecakapan kerjasama siswa adalah melakukan pembelajaran menggunakan model discovery learning. Menurut Suhana (2014: 44) discovery learning adalah rangkaian kegiatan pembelajaran yang menghendaki siswa untuk mencari dan menyelidiki secara sistematis, kritis dan logis. Menurut Depdikbud (2014:45) ada enam tahapan dalam pembelajaran model discovery learning yaitu: stimulasi/pemberian rangsangan yang diharapkan untuk merangsang pikiran siswa untuk berpikir kritis, perumusan masalah yang diharapkan untuk membantu siswa berpikir kritis, pengumpulan data dan pengolahan data yang diharapkan untuk membantu siswa bekerjasama dalam kelompok, pembuktian diharapkan membantu siswa untuk mempertimbangkan kebenaran fakta, dan menarik kesimpulan.

Morocco et al dalam Abidin (2014:8) mengemukakan bahwa pada abad ke -21 kompetensi belajar yang harus dimiliki siswa yaitu kemampuan pemahaman yang tinggi, kemampuan berpikir kritis. Pembelajaran dengan model discovery learning diharapkan siswa dapat memiliki kemampuan berpikir kritis, melatih siswa memiliki kemampuan menemukan sendiri konsep dan melatih siswa bekerjasama dalam mengumpulkan dan mengolah data. Hal ini diperkuat dengan jurnal penelitian oleh Fransiska (2017: 490) yang menyimpulkan bahwa model discovery learning dapat meningkatkan kemampuan berpikir kritis siswa pada pembelajaran IPA SMPN 2 Blitar.

Untuk itu peneliti melakukan penelitian dengan judul "Penerapan Model Discovery Learning untuk Meningkatkan Kemampuan Berpikir Kritis dan Kecakapan Kerjasama Pada Pembelajaran IPA Siswa Kelas V SD Negeri 32 Bengkulu Tengah". Berdasarkan latar belakang yang dikemukakan, maka rumusan masalah dalam penelitian ini adalah: Apakah penerapan model discovery learning dapat meningkatkan kemampuan berpikir kritis siswa kelas V SD Negeri 32 
Penerapan Model Discovery Learning untuk Meningkatkan Kemampuan Berpikir Kritis dan Kecakapan Kerjasama pada Pembelajaran IPA Siswa Kelas V SD Negeri 32

Bengkulu Tengah

Bengkulu Tengah? Apakah penerapan model discovery learning dapat meningkatkan kecakapan kerjasama siswa kelas V SD Negeri 32 Bengkulu Tengah?

Berdasarkan rumusan masalah penelitian yang dikemukakan, maka tujuan dari penelitian ini adalah:

1. Meningkatkan kemampuan berpikir kritis siswa kelas V SD Negeri 32 Bengkulu Tengah melalui penerapan model discovery learning.

2. Meningkatkan kecakapan kerjasama siswa kelas V SD Negeri 32 Bengkulu Tengah melalui penerapan model discovery learning.

Manfaat yang diperoleh dari penelitian tindakan ini adalah:

a) Bagi siswa, untuk memperoleh pengetahuan yang lebih dengan meningkatnya kemampuan berpikir kritis dan kecakapan kerjasama siswa.

b) Bagi guru, sebagai sarana untuk membuat variasi mengajar dalam memperbaiki dan meningkatkan pembelajaran di kelas.

c) Bagi sekolah, sebagai sarana informasi dalam meningkatkan proses pembelajaran.

d) Bagi peneliti, sebagai sarana informasi untuk merancang pembelajaran yang lebih baik.

IPA merupakan mata pelajaran yang penting pada jenjang sekolah dasar.

Menurut Samatowa (2016: 4) IPA merupakan pembelajaran yang mengikuti metode menemukan sendiri untuk melatih siswa agar dapat berpikir krtis dan objektif. Pembelajaran IPA di SD lebih menekankan pada pemberian pengalaman langsung bagi siswa. Menurut Samatowa (2016: 5) aspek pokok dalam proses pembelajaran IPA adalah anak dapat menyadari keterbatasan pengetahuan mereka, memiliki rasa ingin tahu untuk menggali berbagai pengetahuan baru, dan akhirnya dapat mengaplikasikannya dalam kehidupan.

Salah satu model pembelajaran yang digunakan dalam pembelajaran IPA adalah model discovery learning. Menurut Kokom (2014:44) discovery learning merupakan kegiatan pembelajaran yang melibatkan seluruh kemampuan siswa untuk mencari dan menyelidiki secara sistematis, kritis dan logis sehingga mereka dapat menemukan sendiri konsep yang dipelajari. Model discovery learning menuntut siswa dapat menemukan sendiri konsep yang dipelajari.

Pembelajaran hendaknya dapat menciptakan situasi belajar yang melibatkan siswa sehingga siswa dapat belajar melalui pengalaman dan eksperimen untuk menemukan pengetahuan yang khas. Jurnal penelitian yang dilakukan oleh Balim (2009) menyimpulkan bahwa prestasi akademik kelompok eksperimen lebih baik dengan menggunakan model discovery learning dibandingkan kelompok kontrol yang 
hanya menggunakan pembelajaran konvensional.

Dari beberapa penjelasan di atas bahwa model discovery learning adalah model pembelajaran yang menuntut siswa sendiri mencari informasi dan membangun pengetahuan mereka sendiri melalui eksperimen atau menemukan sendiri konsep-konsep yang sedang mereka pelajari. Dengan penerapan model ini, siswa dituntut untuk berpikir lebih kritis.

Depdikbud (2014:45) menyatakan tahapan dalam pembelajaran yang menerapkan discovery learning ada enam, yaitu:

1. Stimulasi/pemberian rangsangan. Pada tahap ini siswa dihadapkan pada sesuatu yang menimbulkan rasa ingin tahu siswa.

2. Pernyataan/ identifikasi masalah. Pada tahap ini, guru memberi kesempatan kepada siswa untuk mengidentifikasi masalah yang relevan dengan materi.

3. Pengumpulan data. Pada tahap ini siswa diberi kesempatan untuk mengumpulkan berbagai informasi yang relevan, melakukan percobaan sendiri dan sebagainya.

4. Pengolahan data. Pada tahap ini siswa akan mengolah data yang diperoleh dari berbagai informasi, semua data tersebut akan diolah menjadi suatu hasil laporan.

5. Pembuktian. Pada tahap ini siswa melakukan pemeriksaan untuk membuktikan benar atau tidaknya hipotesis yang telah dirumuskan.

6. Menarik kesimpulan/generalisasi. Tahap generalisasi atau menarik kesimpulan adalah proses menarik sebuah kesimpulan yang dijadikan prinsip umum untuk semua masalah.

Keterampilan berpikir kritis dalam penelitian ini merujuk pada indikator berpikir kritis menurut Ennis dalam Winarni, (2012:155), yaitu: “(1) memberi penjelasan sederhana, meliputi : memfokuskan pertanyaan, menganalisis pertanyaan, bertanya dan menjawab pertanyaan tentang suatu penjelasan; (2) membangun keterampilan dasar, meliputi: mempertimbangkan apakah suatu sumber dapat dipercaya/ tidak, mengamati dan mempertimbangkan suatu laporan hasil observasi; (3) menyimpulkan, meliputi: mendeduksi dan mempertimbangkan deduksi, menginduksi dan mempertimbangkan hasil induksi, dan membuat dan menentukan nilai pertimbangan". Salah satu kecakapan hidup yang harus dikuasai siswa adalah kecakapan sosial, contohnya kecakapan kerjasama. Kecakapan kerjasama antar siswa perlu ditingkatkan melalui kegiatan kerja kelompok. Pembelajaran IPA dengan model discovery learning memiliki langkah-langkah kegiatan yang menuntut siswa untuk mampu bekerja sama dalam kelompok. 


\section{Penerapan Model Discovery Learning untuk Meningkatkan Kemampuan Berpikir Kritis dan Kecakapan Kerjasama pada Pembelajaran IPA Siswa Kelas V SD Negeri 32 Bengkulu Tengah}

Menurut Samani (2012: 118) sikap kerjasama adalah tindakan bekerjasama dengan orang lain untuk mencapai suatu tujuan yang memiliki keuntungan bersama. Proses pembelajaran dengan menggunakan model discovery learning menekankan pada proses kerjasama dalam kelompok. Keberhasilan pembelajaran kelompok ditentukan oleh keberhasilan secara kelompok melalui kerjasama yang baik. Menurut Rusman (2011: 207) keterampilan bekerja sama dipraktikan melalui aktivitas dalam kegiatan pembelajaran secara berkelompok. Dari beberapa pendapat di atas disimpulkan bahwa kerjasama adalah usaha yang dilakukan oleh siswa di dalam kelompok melalui aktivitas pembelajaran untuk mencapai tujuan pembelajaran yang dikehendaki. Kecakapan kerjasama sangat diperlukan dalam pembelajaran.

Kecakapan kerjasama siswa terlihat selama pembelajaran berlangsung. Pembelajaran dengan model discovery learning dituntut untuk memberikan kecakapan khusus agar siswa dapat bekerjasama dengan baik, misalnya menjadi aktif untuk bekerjasama dalam kelompok. (Slavin dalam Jauhar 2011:53) Menurut Kemendiknas (2010:36), indikator kerjasama siswa dalam kelompok terdiri dari:

1. Memberikan pendapat dalam kerja kelompok di kelas

2. Memberi dan mendengarkan pendapat dalam diskusi kelas

3. Ikut dalam kegiatan sosial dan budaya sekolah

\section{Metode}

Jenis penelitian yang digunakan dalam penelitian ini adalah penelitian tindakan kelas (PTK). Penelitian dilakukan di SD Negeri 32 Kabupaten Bengkulu Tengah. Subjek penelitian adalah guru dan siswa kelas V yang berjumlah 11 orang perempuan dan 13 laki-laki. Penelitian telah dilaksanakan pada semester genap tahun pelajaran 2017/2018

Penelitian ini adalah penelitian tindakan kelas (PTK). Prosedur penelitian terdapat empat tahapan yaitu: (a) perencanaan, (b) tindakan, (c) pengamatan, dan (d) refleksi. Keempat tahapan dapat dilaksanakan pada setiap siklus hingga mencapai hasil yang diharapkan.

Instrumen penelitian yang digunakan berupa lembar observasi dan lembar tes. Teknik mengumpulkan data dalam penelitian ini: 1) Teknik tes ini dilakukan dengan menggunakan tes tertulis dalam bentuk uraian 2) Teknik non tes ini dilakukan dengan penilaian lembar observasi saat pembelajaran sedang berlangsung.

Teknik analisis data yang digunakan merupakan gabungan pengolahan data kualitatif dan kuantitatif. 1. Data Hasil Observasi (Observasi kerjasama). 
Analisis data hasil observasi yaitu teknik deskriptif kuantitatif dengan menghitung rata-rata (mean) dan standar deviasi skor pengamat untuk setiap indikator pengamatan dengan rumus:

$$
\mathrm{B}=\frac{\sum \text { Sepakat Perolehan }}{\sum \text { Skor Keseluruhan }} \times 100 \%
$$

Perolehan skor kecakapan kerjasama siswa diolah dengan langkah:

1. Menentukan skor terendah dan skor tertinggi

2. Mencari rata-rata 3. Membagi rentang nilai menjadi

3 kategori yaitu: Baik, Sedang, dan Kurang

Menggunakan rumus:

$$
N p=\frac{R}{S m} \times 100
$$

Keterangan:

NP: nilai yang dicari atau diharapkan

$\mathrm{R}$ : Skor observasi yang bersangkutan

Sm : skor maksimal observasi

100 : bilangan tetap

2. Data Tes

Teknik analisis data yang digunakan adalah teknik analisis data kuantitatif. Adapun penyajian data kuantitatif dalam bentuk persentasi dan angka. Rumus presentase (Aqib, 2010:41) sebagai berikut.

$$
\text { B }=\frac{\sum \text { siswa yang tuntas belajar }}{\sum \text { seluruh siswa }} \times 100 \%
$$

Hasil

\section{Hasil Kemampuan Berpikir Kritis Siswa}

a. Siklus I

Penilaian kemampuan berpikir kritis siswa pada siklus I mencakup empat indikator,

yaitu: (1) Memberikan penjelasan secara sederhana (memfokuskan pertanyaan), (2) Memberikan penjelasan secara sederhana (menjawab pertanyaan tentang suatu penjelasan), (3) Membangun keterampilan dasar (mempertimbangkan apakah sumber dapat dipercaya), (4) Menyimpulkan (menginduksi dan mempertimbangkan hasil induksi). Perolehan hasil belajar pada siklus I dapat dilihat dalam Tabel 4.1. 
Penerapan Model Discovery Learning untuk Meningkatkan Kemampuan Berpikir Kritis dan Kecakapan Kerjasama pada Pembelajaran IPA Siswa Kelas V SD Negeri 32

Tabel 4.1 Hasil analisis kemampuan berpikir kritis ( $\mathrm{N}=24)$

\begin{tabular}{|c|l|c|}
\hline No. & \multicolumn{1}{|c|}{ Indikator } & $\begin{array}{c}\text { Persentase } \\
\text { siklus }\end{array}$ \\
\hline 1 & Memfokuskan pertanyaan & $59 \%$ \\
\hline 2 & $\begin{array}{l}\text { Menjawab pertanyaan tentang suat } \\
\text { penjelasan }\end{array}$ & $62 \%$ \\
\hline 3 & $\begin{array}{l}\text { Membangun keterampilan dasar } \\
\text { (mempertimbangkan apakah } \\
\text { sumber dapat dipercaya) }\end{array}$ & $64 \%$ \\
\hline 4 & $\begin{array}{l}\text { Menyimpulkan (menginduksi dan } \\
\text { mempertimbangkan hasil induksi). }\end{array}$ & $54 \%$ \\
\hline
\end{tabular}

Dari Tabel 4.1, menunjukkan bahwa pada hasil kemampuan berpikir kritis siswa pada indikator memberikan penjelasan secara sederhana (memfokuskan pertanyaan) diperoleh persentase sebesar 59\%. Pada indikator memberikan penjelasan secara sederhana (menjawab pertanyaan tentang suatu penjelasan) diperoleh persentase sebesar $62 \%$. Pada indikator membangun keterampilan dasar (mempertimbangkan apakah sumber dapat dipercaya) diperoleh persentase sebesar 64\%. Pada indikator menyimpulkan (menginduksi dan mempertimbangkan hasil induksi) diperoleh persentase sebesar 54\%.

\section{b. Siklus II}

Perolehan hasil belajar siswa pada siklus II telah mengalami peningkatan, karena siswa telah memahami tentang materi ajar, siswa juga telah memahami indikator berpikir kritis dan memahami model discovery learning. Perolehan hasil belajar pada siklus II dapat dilihat dalam Tabel 4.2.

Tabel 4.2 Hasil analisis kemampuan berpikir kritis (N=24) Siklus II

\begin{tabular}{|c|l|c|}
\hline No. & \multicolumn{1}{|c|}{ Indikator } & Persentase \\
\hline 1 & Memfokuskan pertanyaan & $68 \%$ \\
\hline 2 & $\begin{array}{l}\text { Menjawab pertanyaan tentang suatu } \\
\text { penjelasan }\end{array}$ & $77 \%$ \\
\hline 3 & $\begin{array}{l}\text { Membangun keterampilan dasar } \\
\text { (mempertimbangkan apakah sumber } \\
\text { dapat dipercaya) }\end{array}$ & $75 \%$ \\
\hline 4 & $\begin{array}{l}\text { Menyimpulkan (menginduksi dan } \\
\text { mempertimbangkan hasil induksi). }\end{array}$ \\
\hline
\end{tabular}


Dari Tabel 4.2, menunjukkan bahwa pada hasil kemampuan berpikir kritis siswa pada indikator memfokuskan pertanyaan diperoleh persentase sebesar $68 \%$. Pada indikator menjawab pertanyaan tentang suatu penjelasan diperoleh persentase sebesar 77\%. Pada indikator membangun keterampilan dasar (mempertimbangkan apakah sumber dapat dipercaya) diperoleh persentase sebesar $75 \%$. Pada indikator menyimpulkan (menginduksi dan mempertimbangkan hasil induksi) diperoleh persentase sebesar $60 \%$.

\section{a. Siklus III}

Perolehan hasil belajar pada siklus III telah mengalami peningkatan, karena guru dan siswa telah memahami model discovery learning yang diterapkan. Siswa mampu berpikir secara kritis dalam menjawab soal evaluasi yang diberikan oleh guru. Perolehan nilai kemampuan berpikir kritis pada siklus III ini dapat dilihat dalam Tabel 4.3.

Tabel 4.3 Hasil analisis kemampuan berpikir kritis (N=24) Siklus III

\begin{tabular}{|c|l|c|}
\hline No. & \multicolumn{1}{|c|}{ Indikator } & Persentase \\
\hline 1 & Memfokuskan pertanyaan & $81 \%$ \\
\hline 2 & $\begin{array}{l}\text { Menjawab pertanyaan tentang suatu } \\
\text { penjelasan }\end{array}$ & $82 \%$ \\
\hline 3 & $\begin{array}{l}\text { Membangun dasar } \\
\text { (mempertimbangkan apakah sumber dapat } \\
\text { dipercaya) }\end{array}$ & $90 \%$ \\
\hline 4 & $\begin{array}{l}\text { Menyimpulkan dan } \\
\text { mempertimbangkan hasil induksi). }\end{array}$ \\
\hline
\end{tabular}

Dari Tabel 4.3, menunjukkan bahwa hasil kemampuan berpikir kritis siswa pada indikator memfokuskan pertanyaan diperoleh persentase sebesar $81 \%$. Pada indikator menjawab pertanyaan tentang suatu penjelasan diperoleh persentase sebesar $82 \%$. Pada indikator membangun keterampilan dasar (mempertimbangkan apakah sumber dapat dipercaya) diperoleh persentase sebesar 90\%. Pada indikator menyimpulkan (menginduksi dan mempertimbangkan hasil induksi) diperoleh persentase sebesar $80 \%$.

\section{Hasil Kecakapan Kerjasama Siswa}

\section{a. Siklus I}

Pada pengamatan kecakapan siswa, siswa belum terlibat aktif dalam kelompok, siswa belum berani mengemukakan pendapat dalam kelompok dan siswa 
Penerapan Model Discovery Learning untuk Meningkatkan Kemampuan Berpikir Kritis dan Kecakapan Kerjasama pada Pembelajaran IPA Siswa Kelas V SD Negeri 32

Bengkulu Tengah

belum mampu beradaptasi dengan kelompoknya. Hasil pengamatan kecakapan kerjasama siswa pada siklus I dalam Tabel 4.4.

Tabel 4.4 Hasil Penilaian Kecakapan kerjasama siswa Siklus I

\begin{tabular}{|c|l|c|}
\hline No. & \multicolumn{1}{|c|}{ Indikator } & Persentase \\
\hline 1 & $\begin{array}{l}\text { Memberikan pendapat dalam } \\
\text { kerja kelompok di kelas }\end{array}$ & $51 \%$ \\
2 & $\begin{array}{l}\text { Memberi dan mendengarkan } \\
\text { pendapat dalam diskusi kelas }\end{array}$ & $58 \%$ \\
\hline 3 & $\begin{array}{l}\text { Ikut dalam kegiatan sosial dan } \\
\text { budaya sekolah }\end{array}$ & $61 \%$ \\
\hline
\end{tabular}

Dari tabel 4.4 menunjukkan bahwa perolehan persentase pada indikator memberikan pendapat dalam kerja kelompok di kelas sebesar 51\%, pada indikator memberi dan mendengarkan pendapat dalam diskusi kelas sebesar 58\% dan pada indikator ikut dalam kegiatan sosial dan budaya sekolah sebesar $61 \%$ Siklus II.

Pada siklus II, siswa juga telah aktif bekerjasama dalam kelompok, telah berdiskusi dengan baik dalam kelompok, siswa telah berani mengungkapkan pendapatnya. Mayoritas siswa telah beradaptasi dengan teman-temannya dalam kelompok. Hasil pengamatan kecakapan kerjasama siswa pada siklus II seperti dijelaskan dalam Tabel 4.5.

Tabel 4.5 Hasil pengamatan kecakapan kerjasama siswa Siklus II

\begin{tabular}{|c|l|c|}
\hline No. & \multicolumn{1}{|c|}{ Indikator } & Persentase \\
\hline 1 & $\begin{array}{l}\text { Memberikan pendapat dalam kerja } \\
\text { kelompok di kelas }\end{array}$ & $74 \%$ \\
\hline 2 & $\begin{array}{l}\text { Memberi dan mendengarkan pendapat } \\
\text { dalam diskusi kelas }\end{array}$ & $71 \%$ \\
\hline 3 & $\begin{array}{l}\text { Ikut dalam kegiatan sosial dan budaya } \\
\text { sekolah }\end{array}$ \\
\hline
\end{tabular}

Dari Tabel 4.5 menunjukkan bahwa perolehan persentase pada indikator memberikan pendapat dalam kerja kelompok di kelas sebesar $74 \%$, pada indikator memberi dan mendengarkan pendapat dalam diskusi kelas sebesar $71 \%$ dan pada indikator ikut dalam kegiatan sosial dan budaya sekolah sebesar $73 \%$.

\section{b. Siklus III}

Pada siklus III, siswa juga telah aktif bekerjasama dalam kelompok, telah berdiskusi dengan baik dalam kelompok, siswa telah berani mengungkapkan pendapatnya. Mayoritas siswa telah beradaptasi dengan teman-temannya dalam 
kelompok. Hasil pengamatan kecakapan kerjasama siswa pada siklus III seperti dijelaskan dalam Tabel 4.6.

Tabel 4.6 Hasil Penilaian Kecakapan kerjasama siswa Siklus III

\begin{tabular}{|c|l|c|}
\hline No. & \multicolumn{1}{|c|}{ Indikator } & Persentase \\
\hline 1 & $\begin{array}{l}\text { Memberikan pendapat dalam kerja } \\
\text { kelompok di kelas }\end{array}$ & $87 \%$ \\
2 & $\begin{array}{l}\text { Memberi dan mendengarkan } \\
\text { pendapat dalam diskusi kelas }\end{array}$ & $88 \%$ \\
\hline 3 & $\begin{array}{l}\text { Ikut dalam kegiatan sosial dan } \\
\text { budaya sekolah }\end{array}$ & $87 \%$ \\
\hline
\end{tabular}

Dari Tabel 4.6 menunjukkan bahwa perolehan persentase pada indikator memberikan pendapat dalam kerja kelompok di kelas sebesar $87 \%$, pada indikator memberi dan mendengarkan pendapat dalam diskusi kelas sebesar $88 \%$ dan pada indikator ikut dalam kegiatan sosial dan budaya sekolah sebesar $87 \%$.

Kegiatan pembelajaran pada siklus III ini siswa telah mulai memahami bagaimana cara bekerjasama dengan baik. Siswa telah berani berinteraksi dengan siswa lainnya, dan berani mengemukakan pendapat dalam kelompok. Siswa telah memenuhi indikator kecakapan kerjasama.

\section{Pembahasan}

\section{Penerapan Model Discovery Learning Untuk Meningkatkan Kemampuan Berpikir Kritis Siswa}

Pembelajaran menggunakan model discovery learning telah dilakukan dan berjalan sesuai dengan rencana. Pembelajaran dengan model discovery learning bertujuan untuk meningkatkan kemampuan berpikir kritis siswa. Menurut Suhana (2014: 45) model discovery learning dapat membantu siswa mengembangkan, kesiapan serta penguasaan keterampilan dalam proses kognitif.

Penilaian kemampuan berpikir kritis siswa, menggunakan indikator berpikir kritis yaitu: (1) memberi penjelasan sederhana, meliputi : memfokuskan pertanyaan, menganalisis pertanyaan, bertanya dan menjawab pertanyaan tentang suatu penjelasan; (2) membangun keterampilan dasar, meliputi: mempertimbangkan apakah suatu sumber dapat dipercaya/tidak, mengamati dan mempertimbangkan suatu laporan hasil observasi; (3) menyimpulkan, meliputi: mendeduksi dan mempertimbangkan deduksi, menginduksi dan mempertimbangkan hasil induksi, membuat dan menentukan nilai pertimbangan. 
Penerapan Model Discovery Learning untuk Meningkatkan Kemampuan Berpikir Kritis dan Kecakapan Kerjasama pada Pembelajaran IPA Siswa Kelas V SD Negeri 32

Bengkulu Tengah

Dalam pembelajaran selama 3 siklus penelitian, pembelajaran dengan model discovery learning membuat siswa mampu memenuhi indikator berpikir kritis. Siswa telah mampu memberi penjelasan sederhana (memfokuskan pertanyaan) ditunjukkan dengan perolehan persentase kelas secara klasikal mengalami peningkatan yaitu pada siklus 1 sebesar $59 \%$, siklus II sebesar $68 \%$ dan siklus III sebesar $81 \%$.

Pembelajaran dengan model discovery learning membuat siswa berani bertanya dan menjawab pertanyaan, siswa telah mampu bertanya dan menjawab pertanyaan tentang suatu penjelasan ditunjukkan dengan perolehan persentase kelas secara klasikal mengalami peningkatan yaitu pada siklus 1 sebesar $62 \%$, siklus II sebesar 77\% dan siklus III sebesar 82\%. Sejalan dengan penelitian oleh Fransiska (2017) dengan judul "Penerapan Strategi Discovery Learning (DL) Untuk Meningkatkan Keterampilan Berpikir Kritis Dan Pemahaman Konsep IPA” yang menunjukkan bahwa discovery learning dapat meningkatkan keterampilan berpikir kritis, karena discovery learning merupakan pembelajaran berpokus pada konsep yang melibatkan siswa secara aktif dalam kegiatan pemecahan masalah dan tugas bermakna lainnya.

Siswa telah mampu membangun keterampilan dasar dengan mempertimbangkan apakah suatu sumber dapat dipercaya/tidak ditunjukkan dengan perolehan persentase kelas secara klasikal pada siklus 1 sebesar 64\%, siklus II sebesar $75 \%$ dan siklus III sebesar 90\%. Siswa telah mampu memecahkan masalah yang telah dirumuskan. Menurut Jhonson dalam Nurhayati (2011:67) berpikir kritis berperan dalam mengambil keputusan dan memecahkan masalah yang dirumuskan.

Siswa telah mampu menyimpulkan dengan menginduksi dan mempertimbangkan hasil induksi ditunjukkan dengan perolehan persentase kelas pada siklus I sebesar 54\%, siklus II sebesar $60 \%$ dan siklus III sebesar $80 \%$. Sejalan dengan hasil penelitian Luthfi dkk. (2015) menyimpulkan bahwa model discovery learning dapat meningkatkan keterampilan berpikir kritis siswa dengan peningkatan pada setiap siklus.

\section{Penerapan Model Discovery Learning untuk meningkatkan kecakapan} kerjasama Siswa

Pembelajaran dengan model dicovery learning telah melatih siswa untuk bekerjasama dalam kelompok. Tahap pengumpulan data, siswa dilatih bekerjasama mencari informasi dalam kelompok. Kelebihan dari model pembelajaran discovery learning menurut Putrayasa (2014) yaitu: memberikan kesempatan kepada siswa 
untuk mendapatkan informasi dari sumber pengetahuan selain buku, meningkatkan kerjasama antar siswa untuk melatih kecakapan kerjasama siswa.

Pembelajaran dengan model discovery learning mdmbuat siswa berkelompok, kemudian siswa mendiskusikan pertanyaan di lembar LKS untuk menemukan konsep tentang materi yang dipelajari dengan satu tujuan yang sama yaitu merumuskan masalah dan memecahkannya. Tindakan bekerjasama dengan orang lain untuk mencapai suatu tujuan yang sama (Samani, 2012: 118).

Selama 3 siklus, pembelajaran dengan menggunakan model discovery learning menjadikan siswa mampu memenuhi indikator kecakapan kerjasama menurut Kemendiknas (2010:36) yaitu: memberikan pendapat dalam kerja kelompok di kelas (berdiskusi dalam memecahkan permasalahan bersama kelompoknya, memberi pendapat pada saat berdiskusi), memberi dan mendengarkan pendapat dalam diskusi kelas (membantu teman kelompoknya yang merasa kesulitan, menerima pendapat dari teman dalam kelompok) dan ikut dalam kegiatan sosial dan budaya sekolah (dapat beradaptasi dengan kelompoknya dan kompak dalam tim).

Siswa telah mampu memberikan pendapat saat kerjasama dalam memecahkan masalah, siswa telah berani mengemukakan pendapatnya, dibuktikan dengan perolehan persentase hasil pengamatan kecakapan kerjasama siswa pada indikator memberikan pendapat dalam kerja kelompok di kelas pada siklus I sebesar $51 \%$, siklus II sebesar $74 \%$ dan siklus III sebesar $87 \%$ dengan kategori baik. Pada siklus 1 hingga ke siklus III siswa mulai bertahap mengalami peningkatan, siswa telah mampu memberi dan mendengarkan pendapat temannya dalam kelompok pada indikator memberi dan mendengarkan pendapat dalam diskusi kelas diperoleh persentase secara klasikal pada siklus I sebesar 58\%, siklus II sebesar 71\% dan siklus III sebesar $82 \%$ dengan kategori baik.

Pada saat diskusi siswa telah mampu beradaptasi dengan teman sekelompoknya, karena pada indikator ikut dalam kegiatan sosial dan budaya sekolah pada siklus I sebesar 60\%, siklus II sebesar 73\% dan siklus III sebesar 87\% dengan kategori baik. Djamarah (2014: 7) menyatakan bahwa pada kegiatan kerjasama semua siswa akan menyebutkan kelebihan dan kekurangannya masingmasing sehingga siswa saling membantu.

\section{Kesimpulan}

Berdasarkan hasil penelitian tindakan kelas yang dilaksanakan di kelas V SD Negeri 32 Bengkulu Tengah maka disimpulkan bahwa penerapan model discovery learning dapat meningkatkan kemampuan berpikir kritis dan kecakapan kerjasama pada pembelajaran IPA. Hal ini ditunjukkan dengan: 
Penerapan Model Discovery Learning untuk Meningkatkan Kemampuan Berpikir Kritis dan Kecakapan Kerjasama pada Pembelajaran IPA Siswa Kelas V SD Negeri 32 Bengkulu Tengah

1. Pada kemampuan berpikir kritis siswa pada indikator memberikan penjelasan secara sederhana untuk sub indikator memfokuskan pertanyaan perolehan persentase meningkat menjadi $81 \%$ dan sub indikator menjawab pertanyaan tentang suatu penjelasan meningkat menjadi 82\%. Indikator kemampuan berpikir kritis yang memperoleh persentase tertinggi yaitu pada indikator membangun keterampilan dasar dengan sub indikator mempertimbangkan apakah sumber dapat dipercaya sebesar $90 \%$. Karena pada indikator ini, siswa telah memahami cara mempertimbangkan sumber informasi yang dipercaya. Indikator kemampuan berpikir kritis yang memperoleh persentase terendah yaitu pada indikator menyimpulkan dengan sub indikator menginduksi dan mempertimbangkan hasil induksi hanya meningkat menjadi $80 \%$, siswa masih perlu dibimbing untuk menyimpulkan suatu pernyataan.

2. Pada observasi kecakapan kerjasama siswa pada indikator memberikan pendapat dalam kelompok perolehan persentase meningkat menjadi $87 \%$. Pada indikator ikut melaksanakan budaya sekolah meningkat menjadi 87\%. Perolehan persentase tertinggi pada kecakapan kerjasama siswa ada pada indikator memberikan dan mendengarkan pendapat di kelas meningkat menjadi $88 \%$.

\section{Saran}

Berdasarkan kesimpulan hasil penelitian penerapan model discovery learning untuk meningkatkan keterampilan berpikir kritis dan kecakapan kerjasama pada pembelajaran IPA siswa kelas V SD Negeri 32 Bengkulu Tengah semester II Tahun Pelajaran 2017/2018, maka peneliti dapat mengemukakan saran yaitu:

a. Guru hendaknya melatih siswa dalam memfokuskan pertanyaan dan menjawab pertanyaan tentang suatu penjelasan, siswa yang belum mampu menyimpulkan hasil diskusi agar indikator menyimpulkan bisa memperoleh persentase yang lebih tinggi.

b. Guru hendaknya membimbing siswa dalam bekerjasama dan berinteraksi dengan kelompok lain.

\section{Referensi}

Balim, A.G (2009). The Effects Of Discovery Learning On Student Success And Inqury Learning Skills. Eurasian Journal of Education research, issu 35, 1-20. Diakses pada 5 Februari 2018. 
Fransiska, Maria dkk. 2017. Penerapan Strategi Discovery Learning (DL) Untuk Meningkatkan Keterampilan Berpikir Kritis Dan Pemahaman Konsep IPA. Journal Inovasi Pembelajaran. Jurnal Inovasi Pembelajaran. Volume 3. EISSN 2460-0873. Diakses pada 5 Februari 2018.

Luthfi, Nur dkk. 2015. Implementasi Pendekatan Saintifik Melalui Discovery Learning dalm Peningkatan Keterampilan Bepikir Kritis Pembelajaran IPA di Kelas IV. Diakses pada 5 Februari 2018.

Aqib, Zainal. 2010. Penelitian Tindakan Kelas. Bandung: YRAMA SWIDIA.

Depdiknas. 2006. Kurikulum Tingkat Satuan Pendidikan (KTSP). Jakarta: Departemen Pendidikan Nasional.

Djamarah, Syaiful Bahri dan Zain, Aswan. 2006. Strategi Belajar Mengajar. Cet-5. Jakarta: Rineka Cipta.

Faiz, Fahrudin. 2012. Thingking Skil (Pengantar Menuju Berpikir Kritis). Yogyakarta: SUKA-Pres UIN Sunan Kalijaga.

Jauhar, Muhammad. 2011. Implementasi PAIKEM. Jakarta: Prestasi Pustaka.

Kemendikbud. 2013. Materi Pelatihan Guru Implementasi Kurikulum 2013. Jakarta: Kemendikbud.

Kemendiknas. 2010. Pendidikan Berkarakter. Jakarta: kemendiknas.

Komalasari, Kokom. 2014. Pembelajaran Kontekstual (Konsep dan Aplikasi). Bandung: PT.Refika Aditama.

Nurhayati, Eti. 2011. Psikologi Pendidikan Inovatif. Yogyakarta: Pustaka Pelajar.

Rusman. 2011. Model-Model Pembelajaran. Jakarta: PT. Rajagrafindo Persada.

Samani, Muchlas dan Haryanto. 2012. Pendidikan Karakter: Konsep dan Model. Bandung: Remaja Rosdakaya.

Samatowa, Usman. 2016. Pembelajaran IPA di Sekolah Dasar. Jakarta: Indeks.

Suhana, Cucu. 2014. Konsep Strategi Pembelajaran. Bandung: Refika Aditama.

Suyono \& Haryanto. 2011. Belajar dan Pembelajaran. Bandung: PT. Remaja Rosdakarya.

Winarni, E. W. (2012). Inovasi pembelajaran IPA. Bengkulu, FKIP Unib Pres. (4)151155. 